\title{
LEDER
}

\section{Progression og studiefremdrift}

\author{
Frederik Voetmann Christiansen, lektor, Københavns Universitet.
}

Den universitetspolitiske diskussion i efteråret har været præget af den såkaldte 'fremdriftsreform' der kombinerer en SU-reform (vedtaget i foråret) med ændringer til en række bekendtgørelser. Reformen, der blandt andet indebærer tvangstilmelding til 60 ECTS eksamener årligt uden mulighed for framelding, skal frem mod 2020 nedbringe den gennemsnitlige studietid med 4,3 måneder. I forhold til universiteternes finansiering vil en del af færdiggørelsesbonussen (930 millioner) gøres afhængig af, at universiteterne samlet set når målet. De studerende der bliver mere end et halvt år forsinket i deres studie vil miste retten til SU, indtil det forsømte er indhentet.

Reformen rammer dermed både de studerende og universiteternes undervisning økonomisk, hvis ikke studietiderne nedbringes. Om end undersøgelser viser, at nogle studerende bruger mindre tid på deres studie end man kunne forvente, virker det mere rimeligt at placere ansvaret for de lange studietider på universitetet end på de studerende. Et argument for dette er den store variation i studietider fra universitet til universitet. På KU gennemførte fx 1 ud af 4 på en humanistisk bacheloruddannelse på normeret tid. På RUC og CBS var forholdet 1 ud af 2, og i Aalborg 2 ud af 3. Hvad er det, der gør, at der er så markant forskel på uddannelsernes studietider? Skyldes det forskelle i undervisnings- og bedømmelsesformer? Hvordan forklares det så, at $51 \%$ af de humaniorastuderende i Aalborg gennemfører kandidatstudiet på normeret tid, mens de tilsvarende tal for RUC og CBS (der også er projekttunge uddannelser) er hhv. $2 \%$ og $4 \%$ ? Der er noget på spil, der ikke ydes retfærdighed med henvisning til, at de studerende er dovne og ikke gider studere på fuld tid. Tilsyneladende responderer de studerende i planlægningen af deres studie på et system og en studiekultur på det studie, de læser, og studietiderne kan ikke adskilles fra, hvad og hvor de studerende læser.

Hvis målene om kortere studietider skal nås, og kvaliteten skal fasholdes, bør universiteterne sætte massivt ind med øget undervisning, hjælp og vejledning til de studerende, der står i fare for at blive alvorligt forsinkede, og få ryddet op i de forhold, der forsinker de studerende. Man kan frygte, at løsningerne i stedet kan blive at slække på eksamenskravene og eksmatrikulere studerende, der bliver forsinkede. At smide de studerende, der bliver forsinkede, ud vil ganske vist føre til bedre gennemførelsesprocenter, men vil jo ikke føre til et øget kvalificeret arbejdsudbud (som er den politiske ambition). 
De studerendes gennemsnitlige studietid er selvfølgelig et relevant kvantitativt politisk mål for effektiviteten i uddannelsessystemet, men studietiden siger meget lidt om kvaliteten af uddannelsen.

Der er ikke en entydig sammenhæng mellem længden på en uddannelse og udbyttet af den. Hvad bliver betydningen af den foreslåede reform for de studerendes læringsudbytte?

I den universitetspædagogiske forskning har der i de seneste 30 år været fokus på sammenhængen mellem de studerendes oplevelse af undervisningen, deres tilgange til læring og deres læringsudbytte. Ofte skelnes mellem to overordnede tilgange til læring - dybe og overfladiske tilgange. Tilgangen til læring har vist sig at være tæt koblet til læringsudbyttet; mens overfladetilgange nok kan være effektive i forhold til at bestå, er de ikke gode i forhold til at forstå.

Tilgangen til læring er ikke er udtryk for personlighedstræk - den samme studerende kan fx anlægge en overfladetilgang i et kursus, netop fordi vedkommende anlægger en dyb strategi $i$ et andet kursus, der følges i samme semester. Tilgangen til læring betinges dermed af relationen mellem studerende og opfattelsen af de rammer, studiet giver. Den universitetspædagogiske opgave bliver dermed at fremme faktorer, som fører til, at studerende anlægger dybe tilgange til læring frem for overfladiske. Blandt centrale faktorer, der medvirker til dette, er den studerendes opfattelse af eksamensformen, arbejdsbyrden, holdstørrelsen, undervisningsformen, den studerendes tiltro til egne faglige evner, oplevelsen af mulighed for feedback og tidligere erfaringer fra uddannelsessystemet. Det mest interessante i denne sammenhæng er oplevelsen af arbejdsbyrden, som er en af de væsentligste faktorer. Med tvangstilmelding til eksamen og når studerendes mulighed for at opnå SU gøres afhængig af, at forsinkelsen skal indhentes, vil det uden nævneværdig tvivl føre til, at flere studerende vil anlægge overfladetilgange til (større dele af) undervisningen.

Der er næppe tvivl om, at reformen, hvis den gennemføres i den foreliggende form, vil reducere den gennemsnitlige studietid. Det kan imidlertid let blive på bekostning af kvaliteten af undervisningen og antallet af studerende, der gennemfører, og det vil utvivlsomt blive på bekostning af kvaliteten af de studerendes læring. 